\title{
Spectrum and expression analysis of KRIT1 mutations in 121 consecutive and unrelated patients with Cerebral Cavernous Malformations
}

\author{
Florence Cavé-Riant ${ }^{1,2,4}$, Christian Denier ${ }^{1,2,4}$, Pierre Labauge ${ }^{1,3}$, Michaelle Cécillon ${ }^{1,2}$, \\ Jacqueline Maciazek $^{1}$, Anne Joutel ${ }^{1,2}$, Sophie Laberge-le Couteulx ${ }^{1}$, \\ Elisabeth Tournier-Lasserve ${ }^{1,2}$ and the Société Française de Neurochirurgie
}

\author{
${ }^{1}$ INSERM EMI 99-21, Faculté de Médecine Lariboisière, Paris, France; ${ }^{2}$ Laboratoire de Cytogénétique, Hôpital \\ Lariboisière, Assistance Publique-Hôpitaux de Paris, Paris, France; ${ }^{3}$ Service de neurologie, CHU Montpellier Nimes, \\ France
}

Cerebral Cavernous Malformations (CCM/MIM 604214) are vascular malformations characterised by abnormally enlarged capillary cavities without intervening brain parenchyma. Clinical manifestations include seizures, cerebral haemorrhages and focal neurological deficits. They occur as a sporadic or autosomal dominant condition. Most often, sporadic cases have only one lesion and familial cases are characterised by a high frequency of multiple lesions. Three CCM loci were previously mapped on $7 q$ (CCM1), 7p (CCM2) and 3q (CCM3) and CCM1 gene was identified as coding Krit1, a protein of unknown function, which was shown initially to interact in yeast two hybrid assays with Rap1A, a small ras GTPase and more recently to Icap $1 \alpha$, a modulator of $\beta 1$ integrin signal transduction. Herein, we screened KRIT1 gene in 121 unrelated, consecutively recruited, CCM probands having at least one affected relative and/ or showing multiple lesions on cerebral MRI. Fifty-two of these probands (43\%) were shown to carry a KRIT1 mutation. Forty-two distinct mutations were identified including six recurrent ones. Three-quarters of these mutations were located in the C-terminal half of the gene, mostly within exons 13, 15 and 17. All of them are predicted to lead to a premature stop codon. No missense mutation was identified. The only two nucleotide substitutions predicted to be missense mutations led in fact to an abnormal splicing and a premature stop codon. Altogether these data suggest that KRIT1 mRNA decay due to the presence of premature stop codons and Krit1 haploinsufficiency may be the underlying mechanism of CCM. European Journal of Human Genetics (2002) 10, 733 - 740. doi:10.1038/sj.ejhg.5200870

Keywords: Cerebral Cavernous Malformations; Krit1; haploinsufficiency

\section{Introduction}

Cerebral Cavernous Malformations (CCM/OMIM 116860) are vascular malformations, mostly located in the central nervous system and characterised by abnormally enlarged capillary cavities without intervening brain parenchyma. ${ }^{1}$ Most common symptoms include seizures, cerebral haemor-

${ }^{*}$ Correspondence: E Tournier-Lasserve; INSERM EMI 99-21, Faculté de médecine Lariboisière, 10, avenue de Verdun, 75010 Paris, France. Tel: 331448977 50; Fax: 331448977 55;

E-mail: tournier-lasserve@paris7.jussieu.fr

${ }^{4}$ The first two authors contributed equally to the present study.

Received 16 April 2002; revised 24 June 2002; accepted 28 June 2002 rhages and focal neurological deficits. From large series based on necropsy and/or magnetic resonance imaging, their prevalence in the general population has been estimated to be close to $0.1-0.5 \% .^{2}$

Cavernous angiomas can occur as a sporadic or autosomal dominant condition with incomplete penetrance; the frequency of the latter has been estimated as high as $50 \%$ in Hispano-American CCM patients ${ }^{3}$ and is most likely close to $10-20 \%$ in Caucasians (Tournier-Lasserve, unpublished data). Sporadic cases most often harbour only one CCM lesion. On the contrary, familial CCM are characterised by a high frequency of multiple lesions, whose 
number is strongly correlated to patients' age suggesting a dynamic nature of these lesions. "Sporadic' cases harbouring multiple lesions have been shown to be in reality affected by an hereditary form of the disease since $75 \%$ of them have an asymptomatic parent with CCM lesions on brain MRI, due to incomplete clinical penetrance of this condition. ${ }^{4}$ De novo mutation of KRIT1/CCM1 gene has also been reported in one CCM patient with multiple lesions. ${ }^{5}$

Three CCM loci had been previously identified on $7 q$ (CCM1), 7p (CCM2) and 3q (CCM3). ${ }^{6,7}$ Recently, CCM1 was identified as the KRIT1 gene. ${ }^{8,9}$ KRIT1, a protein of unknown function so far, was previously identified through a yeast two-hybrid screen designed to identify proteins interacting with Rap1A, a small Ras like GTPase protein. ${ }^{10}$ KRIT1 encodes a 736 amino-acids protein containing four ankyrin domains, a FERM domain and a C-terminal portion interacting with Rap1A. Comprehensive analysis of KRIT1 has been precluded because the full genomic sequence has been available only very recently. ${ }^{11-14}$ Initially, KRIT1 gene was reported to include 12 coding exons. Screening of these 12 exons led to the identification of germline mutations leading to a premature stop codon or splice mutations whose consequences were not investigated at the cDNA level. ${ }^{8-9,14-18}$ Recently, eight additional exons have been described among which four coding exons. This novel N-terminal region of krit1 has been shown very recently to contain an NPXY motif required for interaction of krit1 with icap $1 \alpha$, a modulator of $\beta 1$ integrin signal transduction. ${ }^{19,20}$ So far, screening of these four novel exons of KRIT1 has been performed only in few families. ${ }^{11,14}$ Almost none of these mutations has been studied at the cDNA level and none of them at the protein level due to unvailability of Krit1 specific antibodies.

In the present study, we searched for KRIT1 mutations in a panel of 121 unrelated, consecutively recruited, CCM probands. Our aims were to estimate the implication of KRIT1 mutations in CCM pathogenesis, to evaluate the distribution and nature of KRIT1 mutations and to investigate the consequences of these mutations on KRIT1 mRNA.

\section{Patients, material and methods \\ Patients}

Twenty-eight French University Neurosurgery Centres participated in this study which was approved by the local ethics comittee. A total of 121 unrelated clinically affected CCM probands were consecutively enrolled in this study. All these patients were known to have at least one affected relative and/or multiple cavernous angiomas on cerebral MRI.

CCM diagnosis was based on cerebral Magnetic Resonance Imaging and/or pathological analysis as described previously; detailed clinical and MRI informations on 57 of these 121 families have been reported elsewhere previously. ${ }^{4}$ A mutation was previously identified in 12 of them. ${ }^{8}$ Detailed clinical and neuroimaging informations were collected for all patients through direct interview and reviewing of medical charts.

\section{Genomic DNA screening}

Genomic DNA from each proband was extracted from peripheral blood using standard procedures. Genomic DNA from 100 unrelated healthy French Caucasian individuals was available as a control group. We screened genomic DNA of all 121 probands using SSCP. ${ }^{21}$ All 16 coding exons were amplified with a set of 19 primers (sequences and PCR conditions on Table 1A). PCR products were electrophoresed on $10 \%$ acrylamide-bisacrylamide 37.5 : 1 gels with $10 \%$ glycerol at $4{ }^{\circ} \mathrm{C}$ on a Mighty small II apparatus at a constant current of $35 \mathrm{~mA}$. Patients' conformers were compared to those of an unrelated healthy individual. Amplimers showing an atypical SSCP banding pattern were directly sequenced (ABI377, Perkin Elmer). Sensitivity of this SSCP procedure was first compared to direct sequence analysis in a panel of 22 unrelated probands belonging to KRIT1 most likely linked families. SSCP analysis run with these conditions (10\% glycerol at $4{ }^{\circ} \mathrm{C}$ ) has detected within this panel all 19 mutations and sequence variants identified by sequence analysis. These SSCP conditions were therefore used for the screening of all remaining probands.

Numbering of nucleotides is according to the full length KRIT1 cDNA (accession number AF296765), beginning nucleotidic numbering at the A of the ATG initiator codon. Mutations were described as recommended by the Ad Hoc Committee on Mutation Nomenclature. ${ }^{22}$

\section{cDNA preparation, cloning and analysis}

Total RNA was extracted from patients lymphoblastoid EBV cell lines or peripheral blood phytohemagglutinin stimulated lymphoblasts and used as samples for cDNA synthesis with oligo $\mathrm{dT}_{15}$ primers and $200 \mathrm{U}$ of Moloney murine leukemia virus (M-MLV) reverse transcriptase (Life Technologies ${ }^{\mathbb{R}}$ ) according to standard procedures. $^{8}$ In order to study cDNA consequences of genomic DNA variants, RT-PCR amplifications were analysed for all probands in whom cDNA were available. cDNAs were amplified with sets of primers located two exons upstream and dowstream of the exon or intron where was located the sequence variant in order to check for aberrant splicing events (sequences and PCR conditions on Table 1B). RT-PCR products from patients and healthy controls were run on $2.5 \%$ Agarose TBE gels. Fragments were sequenced either directly or after cloning using the pGEM $^{\mathbb{R}}-\mathrm{T}$ Easy Vector Systems (Promega ${ }^{\circledR}$, Madison, USA).

\section{Results}

\section{Genomic DNA mutations}

Likely disease causing mutations were identified in a total of 52 probands out of the whole panel of 121 consecutive probands (Table 2 and Figure 1). Mutations were observed in all parts of the gene but were significantly more often located within the second half of the gene, most of them 
Table 1 KRIT1 primers and conditions for the polymerase chain reactions

\begin{tabular}{|c|c|c|c|c|}
\hline \multicolumn{5}{|c|}{ A. Primers for genomic DNA analysis } \\
\hline Exon & Forward primer & Reverse primer & Fragment size & Annealing temperature \\
\hline Exon 4 & CTTGCCATCAAATGTGTC & CAGAATGACATTCAATGG & 210 & 55 \\
\hline Exon 5 & TTTTAAGСТTTСТСТTAATG & АGАATСТTТСТССАСАAG & 247 & 50 \\
\hline Exon 7 & GATGAAAACATGCAGATG & TTCTCAAAGTGTCTGTATC & 282 & 50 \\
\hline \multirow{2}{*}{ Exon 8 a } & САCTTTCGAATGGCTACTTC & ССTGATTCAGTAGCATATGC & 157 & 55 \\
\hline & GAGCGGATAAAAACTAAT & GAGCTAAAАTTCATTCAA & 208 & 50 \\
\hline Exon 11 & AGATGATCTTITTAGGTAAG & ТTACTTGTTATTСАСТGСТT & 275 & 55 \\
\hline Exon 12 & ATGTAATGCCTTTTTTCC & ATGCCTGGCTCTAACTAT & 181 & 55 \\
\hline Exon 13 & TAAAGCACATGAAGTTGAAG & AGTTGTATTTTCTACCAACC & 319 & 55 \\
\hline \multirow{2}{*}{$\begin{array}{r}\text { Exon } 14 \begin{array}{r}a \\
b\end{array}\end{array}$} & TTCAGTACAGAAGTGCAGAC & ТСТСАСАТСТСТTСТTAG & 228 & 55 \\
\hline & TTGCAACATGTTCGTGAC & TTTCTGCСТСTAGTGCTTAC & 204 & 55 \\
\hline Exon 15 & TGTAGCCTAATAACCAAA & AGCATAGCACAAGACCAT & 263 & 50 \\
\hline Exon 16 & АATTACGTTACTGAAAGC & TGTCTTTTCATTTCTATT & 213 & 50 \\
\hline \multicolumn{5}{|c|}{ B. primers for cDNA analysis } \\
\hline Amplified cDNA fragment & Forward primer & Reverse primer & Fragment size & Annealing temperature \\
\hline Exon 4 -exon 10 & АTACTGCСАGTСТСААТTСТС & AGCATGCATAATGAATGG & 933 & 50 \\
\hline Exon 8 -exon 12 & CTAGAGAAAGCAGTACC & GGTTTGTTAATTGCTTCC & 590 & 50 \\
\hline Exon 10 -exon 14 & ССTGTGAAGGAGATTCAG & ТСТСАСАТСТСТTСТTAG & 652 & 50 \\
\hline Exon 12 -exon 14 & TATAACAGACCAACAAGG & TCTCAСАТСТСТTСТTAG & 391 & 50 \\
\hline Exon 12 -exon 17 & TATAACAGACCAACAAGG & CTTTATGATTGCTGGGGC & 815 & 50 \\
\hline Exon 12 -exon 19 & TATAACAGACCAACAAGG & GTGGCTTGAGTAACAGTT & 1189 & 50 \\
\hline Exon $14-$ exon 17 & TTGCAACATGTTCGTGAC & СТTTATGATTGCTGGGGC & 523 & 50 \\
\hline Exon 14 -exon 19 & TTGCAACATGTTCGTGAC & GTGGCTTGAGTAACAGTT & 852 & 50 \\
\hline
\end{tabular}

PCR was carried out under standard conditions: $94^{\circ} \mathrm{C}$ for $3 \mathrm{~min}, 30$ cycles of amplification at $94^{\circ} \mathrm{C}$ for $30 \mathrm{~s}$, specific annealing temperature for $30 \mathrm{~s}$ and $72^{\circ} \mathrm{C}$ for $30 \mathrm{~s}$, and a final extension $10 \mathrm{~min}$ at $72^{\circ} \mathrm{C}$, with a thermocycler Applied Biosystem 9700 .

being located within exons 13, 15 and 17 (56\% of the mutations are located within one of these three exons which span $24 \%$ of the coding sequence). Thirty five per cent of them were exonic nucleotide substitutions leading in most cases to non sense codons, $48 \%$ were small exonic insertions/deletions, $17 \%$ were intronic nucleotide substitutions or deletions (Table 2).

Among the 13 non sense mutations, two were recurrent, R179X and Q455X. Q455X, which was previously identified as a strongly recurrent mutation within CCM hispanoAmerican families, was detected in two distinct families with respective French and Italian backgrounds. A haplotype analysis was performed only within the French pedigree (ped 040) with markers D7S1813, D7S646, D7S558 and D7S689 and did not detect the Hispano-American founder haplotype. Twenty-five probands carried small exonic deletions or insertions leading to a frameshift and premature stop codon; most of them occured in short stretches of repeated sequences. Nine probands were shown to carry an intronic mutation located at canonical splice sites and/or leading to aberrantly spliced transcripts (see below). In addition, we identified in three probands two nucleotide subtitutions located within the coding sequence (pedigree 005 : exon 17/GㅡA 1943 GIA; pedigrees 028 and 054 : exon 15/ㅌCT 1579 ACT).

Expression analysis of the mutations at the cDNA level A total of 30 probands, in whom either an intronic or exonic genomic DNA mutation was identified, were screened, whatever the nature of the mutation, in order to search for aberrant splicing events and screen for the presence of the mutated transcript (Table 2, Figure 2).

Twelve probands carrying a non sense mutation were tested at the cDNA level: in all cases the mutated transcript was detected on sequencing chromatograms, although in most cases its abundance was lower than that of the wild type (as judged on the respective heights of sequence chromatograms peaks). We did not detect any aberrantly spliced transcript in the cDNA of those patients.

cDNA was available for two of the probands carrying canonical splice site mutations IVS7-2 A to G and IVS12-1 $G$ to $A$; those mutations were shown to result respectively in exon 8 skipping (ped 125) and to a $10 \mathrm{bp}$ exonic deletion within exon 13 (ped 136). Only one aberrant transcript was identified for each mutant. Both of these splicing events led to a premature stop codon. The recurrent $4 \mathrm{bp}$ deletion 
Table 2 Nature, location and RNA repercussions of the 52 CCM related KRIT1 mutations

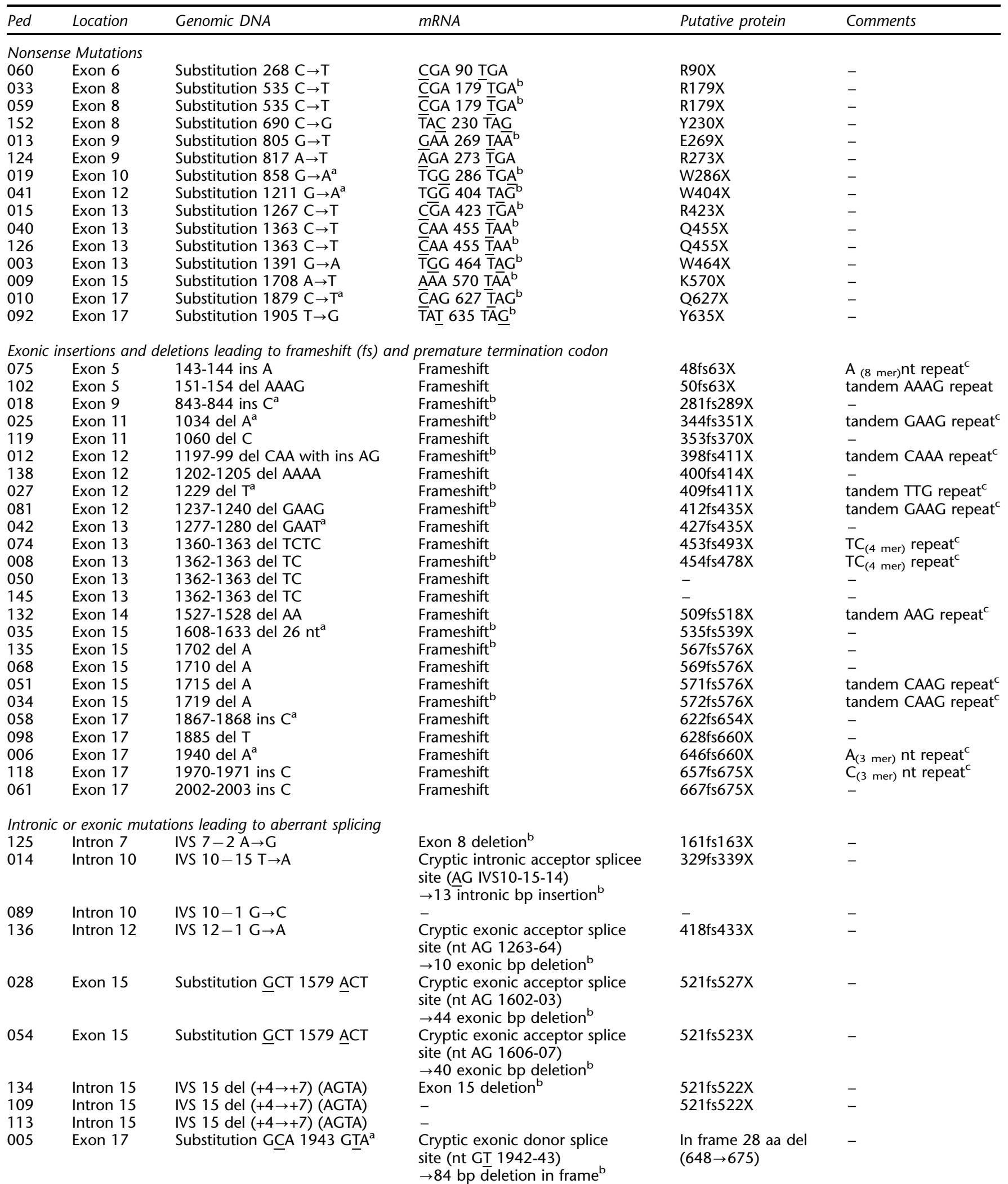


Table 2 (Continued)

\begin{tabular}{|c|c|c|c|c|c|}
\hline Ped & Location & Genomic DNA & $m R N A$ & Putative protein & Comments \\
\hline 011 & Intron 17 & IVS $17-12 \mathrm{~A} \rightarrow \mathrm{G}^{\mathrm{a}}$ & Exon 18 deletion $^{\mathrm{b}}$ & $\begin{array}{l}\text { In frame } 39 \text { aa del } \\
(676 \rightarrow 714)\end{array}$ & - \\
\hline 097 & Intron 17 & IVS $17-12 A \rightarrow G$ & Exon 18 deletion $^{b}$ & $\begin{array}{l}\text { In frame } 39 \text { aa del } \\
(676 \rightarrow 714)\end{array}$ & - \\
\hline
\end{tabular}

apreviously reported mutations (Laberge et al, 1999), ${ }^{\mathrm{b}} \mathrm{RT}$-PCR products were analysed. In all cases, analysed mutant was detected, 'Location of the mutation as regard to short tandem repeats or repeat stretches.

\section{cDNA :}

\begin{tabular}{|c|c|c|c|c|c|c|c|c|c|c|c|c|c|c|c|}
\hline 5'UTR & ATG & & & & & & & & & & & & & & $\mathrm{TG}$ \\
\hline exons $1-3$ & 4 & 5 & \begin{tabular}{l|l}
6 & \\
\end{tabular} & 7 & 8 & 9 & 10 & 11 & 12 & 13 & 14 & 15 & 16 & 17 & \begin{tabular}{l|l|}
18 & 19 \\
\end{tabular} \\
\hline
\end{tabular}

Protein :

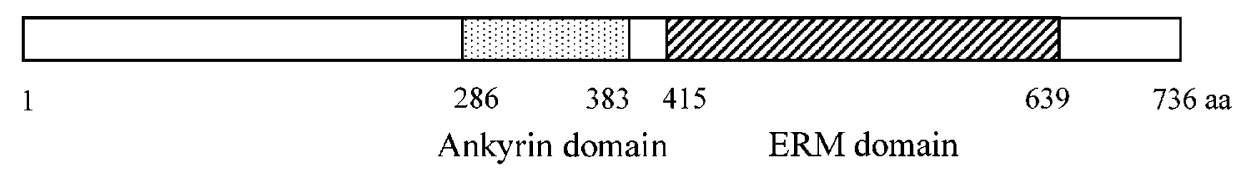

Figure 1 Location of Krit1 mutations.

located within intron 15 (IVS15 $+4 \rightarrow+7$ del AGTA) led to an aberrant transcript deleted of exon 15 and a premature stop codon. The substitution located within IVS10 ( $-15 \mathrm{~T}$ to A) created a new splice site, and led to a transcript with a 13 bp insertion and a premature stop codon. All these aberrant transcripts were detected on RT - PCR cDNA sequence analysis although less abundant than the wild-type ones. Two probands (pedigree 011 and 097) share a common A to $G$ substitution at position -12 within intron 17 ; this mutation was absent in 200 control chromosomes and led to a transcript in which exon 18 has been spliced. Quite interestingly, this abnormal transcript does not harbour a premature stop codon and would lead to an in frame deletion leading to a protein deleted of 39 aa; it was never detected in normal controls.

We identified in three probands two nucleotide subtitutions located within the coding sequence (pedigree 005 : exon 17/GCA 1943 GTA; pedigrees 028 and 054: exon 15/GCT 1579 ACT). Those mutations, if translated, would theoretically lead to a putative protein carrying a missense mutation. When analysing the cDNA of these patients, we showed that these 'missense' mutations led in fact to aberrant transcripts due to destabilisation of preexisting splice sites and utilisation of a cryptic splice site or a newly created site (Figure 2). The aberrant transcript resulting from mutation GCA 1943 GTA, created an acceptor splice site (GT) and led to an $84 \mathrm{bp}$ in frame deletion (Figure 2). This mutation was absent in 200 control chromosomes. This transcript was as abundant as the WT transcript based on chromatograms peak intensity as well as cloning data. Sequence analysis of RT-PCR products in this patient did not detect any normally spliced mature transcript carrying the 'missense' mutation GCA 1943 GTA. The GCT 1579 ACT nt substitution destabilized the WT acceptor splice site of exon 15 leading to the use of a cryptic exonic splice site located downstream of the mutation. Sequence analysis of subcloned RT-PCR detected both wild type transcripts and shorter transcripts due to abnormal splicing events occuring at nucleotides AG 1602-03 (pedigree 028) or 1606-07 (pedigree 054). These abnormal transcripts were not detected in healthy controls. We did not detect any normal sized transcript carrying the expected 'missense' mutation/GCT 1579 ACT.

\section{KRIT1 polymorphisms}

Five other nucleotide substitutions were considered as being most likely polymorphisms based on the fact that they have been observed in both patients and controls or they have been detected in individuals in whom a deleterious mutation has been identified. Three of them were intronic and two exonic. None of them led to an aminoacid substitution. Among these polymorphisms, two (IVS15 -53 $\mathrm{C}>\mathrm{G}$; nt 1809 wobble $\mathrm{T}>\mathrm{C}$ (His603His) in exon 16) were 


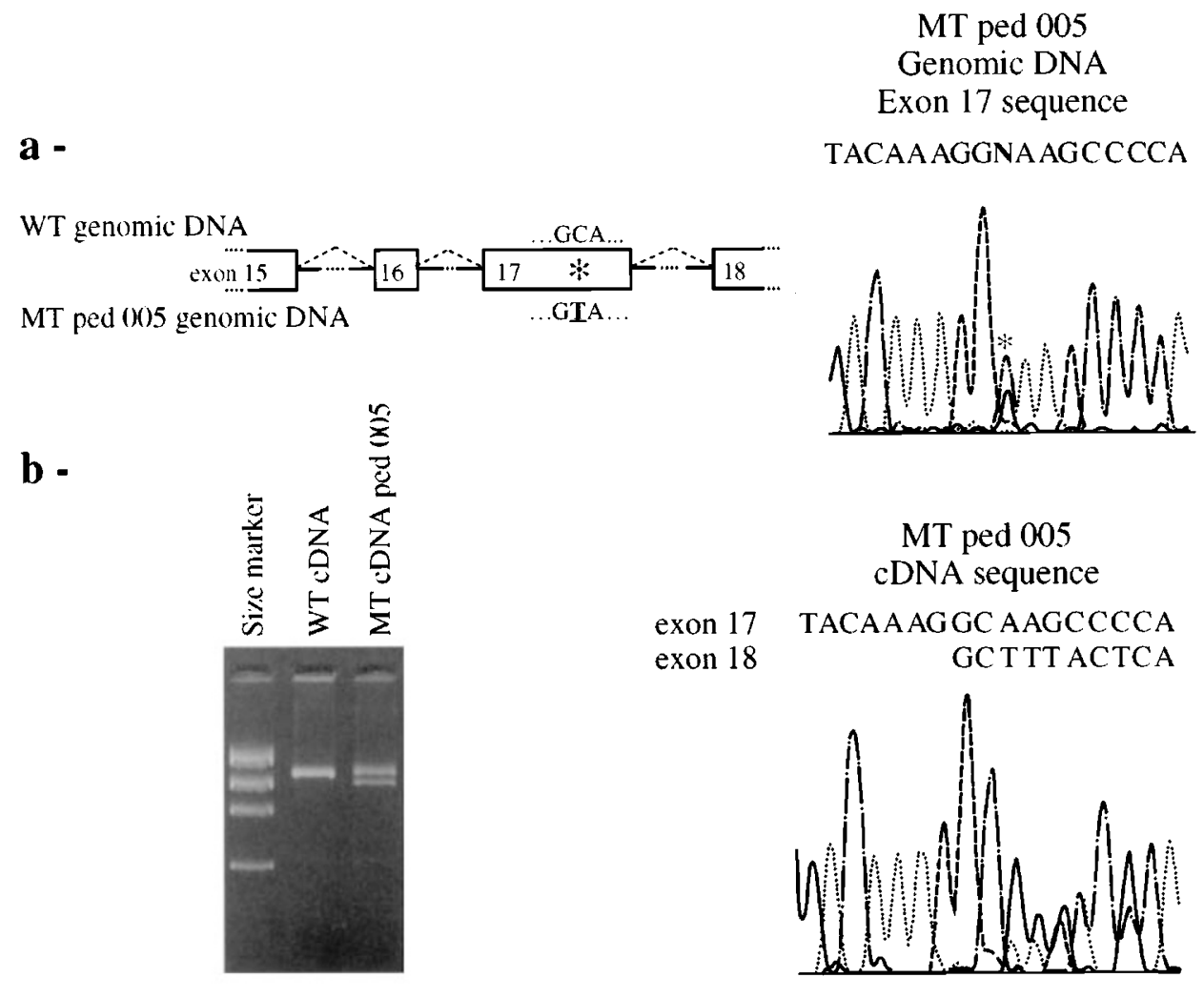

c -

\begin{tabular}{ll|l|l|l|l|} 
WT cDNA & exon 15 & 16 & 17 & 18 \\
\hline
\end{tabular}

WT genomic DNA

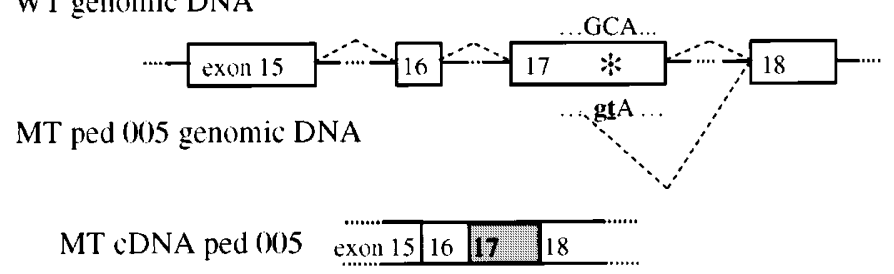

Figure 2 Aberrant splicing resulting from exon 17 nucleotide substitution nt 1943 GCA to GIA in pedigree 005 . Top panel: Left/wild type (WT) and mutated (MT) genomic DNA. *Position of the mutation. Right/genomic DNA sequence chromatogram. Proband 005 is heterozygous for the mutation. Middle panel: Left/WT and MT electrophoresed CDNA RT - PCR products. Two distinct bands are identified for proband 005. Right/Proband 005 cDNA sequence chromatogram. The mutation causes partial skipping of exon 17 leading to a 84 bp in frame deletion. Bottom panel: Use of a new acceptor splice site resulting from nt $1943 \mathrm{C}$ to T mutation.

rare nucleotide substitutions; each of them was detected only in one CCM proband in whom a deleterious mutation has been later on identified (ped 010 and ped 135).

A silent substitution at nt $1980(\mathrm{G}>\mathrm{T} / / \mathrm{Val} 660 \mathrm{Val})$ was detected in an heterozygous state in $25 \%$ of our genotyped population (AA: 72\%//AG: 25\%//GG: 3\%) and was also detected in control individuals.

The last two detected variants were nucleotide substitutions located within intronic sequences: IVS7+65 G/C and IVS10+63 G/C. They have been isolated both in CCM patients and in control individuals. Respective allelic frequencies checked on 100 individuals were

- IVS7+65 G/C: GG: 74\%; GC: 22\%; CC: $4 \%$

- IVS10+63 G/C: GG: 28\%; GC: $45 \%$; CC: $27 \%$

\section{Discussion}

We showed herein that 52 out of 121 consecutively recruited CCM patients having an affected relative and/or showing multiple CCM lesions harbour a KRIT1 mutation. All these 
mutations lead to a premature termination codon through non sense or frameshift mutations except for two of them which lead to small in frame deletions of the C-terminal part of the gene. No missense mutation was identified. Quite strikingly, cDNA analysis showed that the two sole exonic nucleotide substitutions identified did not lead to transcripts carrying the expected 'missense' mutation but to aberrantly spliced transcripts with a premature stop codon.

These data suggest that CCM1/KRIT1 may account for more than $40 \%$ of genetic forms of CCM and are in agreement with multilocus linkage data from others. ${ }^{7}$ However, this proportion is most likely underestimated for several reasons. Based on the strategy that we have used, we may have missed deletions of KRIT1 (however, KRIT1 deletions have not been reported so far), and we may also have missed KRIT1 point mutations due to incomplete SSCP sensitivity. Therefore, this $43 \%$ proportion of KRIT1 positive families should be, in our opinion, considered as a minimum estimate.

The most important result is the stereotyped nature of the mutations on the putative Krit1 protein since almost all of them lead to premature stop codons. It is indeed quite striking that the only two nucleotide substitutions that would be predicted to lead to missense mutations led in fact to aberrantly spliced KRIT1 transcripts and not to any transcript that would be translated with a missense mutation; similar unexpected aberrant splicing has been reported previously for exonic nonsense or missense mutations in BRCA1 and other genes. ${ }^{23}$ Non sense mRNA decay (NMD) as a consequence of premature stop codons has been shown to underlie haploinsufficiency in many disorders. $^{24-27}$ Based on the data reported herein, a putative loss of function of Krit1 through NMD would be a likely mechanism of CCM. However, it would be important, in order to draw a firm conclusion, to check for the presence or the absence of a Krit1 truncated protein, once Krit1 specific antibodies will be available.

This latter information will be quite interesting as regard to recently published data on the interaction of Krit1 and Icap1 $\alpha .{ }^{19,20}$ This interaction required a NPXY motif located within the N-term region of Krit1 at aa residues 191-194 (exon 8). The C-terminal region of KRIT1 has been reported to interact with rap1A. ${ }^{10}$ This interaction with rap1A was not detected by Zhang et al when using the full length krit1 protein; however, a weak interaction was detected when using a Krit1 protein truncated of its N-term. All these data strongly suggest that complex mechanisms may regulate the effects of Krit1 and it would be important to sort out if CCM mutations lead to non sense mRNA decay and absence of the mutated protein or if Krit1 truncated proteins may be present in some CCM patients.

At last, detailed clinical, MRI analysis and genotyping of all consenting symptomatic or asymptomatic at risk individuals will allow in the future to estimate in a sufficient number of individuals the penetrance in families of probands with KRIT1 mutations and to delineate potential genotype-to-phenotype correlations within KRIT1 positive families. Serial follow up of such a genotyped cohort will also help to delineate the natural history of this disease in both groups.

\section{Main clinical investigators}

D Barbieux-Vaquez, S Canaple, D Le Gars (Amiens), J-M de Bray, H Fournier, G Guy, I Penisson-Besnier (Angers), F-X Bergouignan (Bayonne), Beuriat (Beaune), C Bizette, A Czorny, J Godard, G Jacquet (Besançon), J Comoy, P David, D Parker, G Said (Bicêtre), J-P Castel, J Guerin, H Loiseau (Bordeaux), J-P Houtteville, S Khoury, F Viader (Caen), F Attané, C Tannier (Carcassonne), N Carriere, J Chazal, P Clavelou (Clermont-Ferrand), A Nivelon (Dijon), A-L Benabid, J Perret (Grenoble), D Latinville (La Rochelle), Born (Liège), J-C Christiaens, G Combelles, J-P Lejeune, E Louis, F Pasquier (Lille), G Fischer, J-C Froment, J Guyotat, Mortelese, M Sindou (Lyon), H Robert, P Sauvage, J-F Savet (Macon), A Gomez Attarian, G Lena (Marseille), P Richard (Montbéliard), P Coubes Cesari, P Frerebeau Idee (Montpellier), Rey (Narbonne), A Carriere (Nimes), H Hepner, P Lescure, H Vespignani, M Weber (Nancy), S Martin, F Resche Mussini, (Nantes), M Borg, P Grellier, M Lonjon Thomas (Nice), D Rougemont Arthuis (Paris), I Clavier, M Masson, A Redondo, A Rey (Paris, Beaujon), Cophignon, B Georges, M Hagueneau, M Sarrazin, B Silhouette (Paris, Lariboisière), JP Chodkiewicz, B Devaux, F Nataf, F-X Roux (Paris, Sainte-Anne), Y Agid, M Baulac, L Capelle, S Clemenceau, B Dubois, T Faillot, D Fohano, J Philippon (Paris, La Salpétrière), R Gil, F Lapierre, J-P Neau (Poitiers), P Rousseaux (Reims), B Carsin, T Dufour, Y Guegan, J-M Scarabin (Rennes), P Freger (Rouen), J Brunon, M Garnier, D Michel (Saint-Etienne), P Esposito, D Metraut (Strasbourg), B Aesch, François, M Jan, S Velut (Tours), P Arrue, C Bousquet, Y Chaix, M Clanet, N Fabre, G Geraud, Y Lazorthes, C Manelfe, M Tremoulet (Toulouse), Joyeux (Valence).

\section{Acknowledgements}

We thank the families for their participation; all members of the Société Française de Neurochirurgie who participated in this study. $C$ Denier is a recipient of a fellowship from Poste Accueil INSERM. $S$ Laberge-le Couteulx benefited from a studentship from Fonds de Recherche en Santé du Québec and Fondations (1996-99) pour la Recherche Médicale (1999-00). This work was supported by INSERM, AFM, Fondation de France, Ministère Français de la Recherche.

\section{References}

1 Russel DS, Rubinstein LJ: Pathology of Tumors of the Nervous System. 5th edn. Baltimore: Williams and Wilkins, 1989, pp 730-736.

2 Otten P, Pizzolato GP, Rilliet B, Berney J: 131 cases of cavernous angioma (cavernomas) of the CNS, discovered by retrospective analysis of 24,535 autopsies. Neurochirurgie 1989; 35: 82-83, $128-131$. 
3 Rigamonti D, Hadley MN, Drayer BP et al: Cerebral cavernous malformations. Incidence and familial occurrence. $N$ Engl J Med 1988; 319: 343-347.

4 Labauge P, Laberge S, Brunereau L, Levy C, Maciazek J, TournierLasserve E: Hereditary cerebral cavernous angiomas: clinical and genetic features in 57 French families. Société Française de Neurochirurgie. Lancet 1998; 352: $1892-1897$.

5 Lucas M, Costa AF, Montori M, Solano F, Zayas MD, Izquierdo G: Germline mutations in the CCM1 gene, encoding KRIT1, cause cerebral cavernous malformations. Ann Neurol 2001; 49: 529_ 532.

6 Dubovsky J, Zabramski JM, Kurth J et al: A gene responsible for cavernous malformations of the brain maps to chromosome $7 \mathrm{q}$. Hum Mol Genet 1995; 4: 453-458.

7 Craig HD, Gunel M, Cepeda O et al: Multilocus linkage identifies two new loci for a mendelian form of stroke, cerebral cavernous malformation, at 7p15-13 and 3q25.2-27. Hum Mol Genet 1998; 7: $1851-1858$.

8 Laberge-le Couteulx S, Jung HH, Labauge P et al: Truncating mutations in CCM1, encoding KRIT1, cause hereditary cavernous angiomas. Nat Genet 1999; 23: 189-193.

9 Sahoo T, Johnson EW, Thomas JW et al: Mutations in the gene encoding KRIT1, a Krev-1/rap1a binding protein, cause cerebral cavernous malformations (CCM1). Hum Mol Genet 1999; 8: $2325-2333$.

10 Serebriiskii I, Estojak J, Sonoda G, Testa JR, Golemis EA: Association of Krev-1/rap1a with KRIT1, a novel ankyrin repeatcontaining protein encoded by a gene mapping to $7 \mathrm{q} 21-22$. Oncogene 1997; 15: $1043-1049$.

11 Sahoo T, Goenaga-Diaz E, Serebriiskii IG et al: Computational and experimental analyses reveal previously undetected coding exons of the KRIT1 (CCM1) gene. Genomics 2001; 71: 123-126.

12 Zhang J, Clatterbuck RE, Rigamonti D, Dietz HC: Cloning of the murine Krit1 cDNA reveals novel mammalian $5^{\prime}$ coding exons. Genomics 2000; 70: 392-395.

13 Eerola I, McIntyre B, Vikkula M: Identification of eight novel 5'exons in cerebral capillary malformation gene-1 (CCM1) encoding KRIT1. Biochim Biophys Acta 2001; 1517: 464-467.

14 Verlaan DJ, Davenport WJ, Stefan H, Sure U, Siegel AM, Rouleau GA: Cerebral cavernous malformations: Mutations in Krit1. Neurology 2002; 58: 853-857.

15 Davenport WJ, Siegel AM, Dichgans J et al: CCM1 gene mutations in families segregating cerebral cavernous malformations. Neurology 2001; 56: $540-543$.
16 Lucas M, Solano F, Zayas MD et al: Spanish families with cerebral cavernous angioma do not bear $742 \mathrm{C} \rightarrow \mathrm{T}$ Hispanic American mutation of the KRIT1 gene. Ann Neurol 2000; 47836.

17 Eerola I, Plate KH, Spiegel R, Boon LM, Mulliken JB, Vikkula M: KRIT1 is mutated in hyperkeratotic cutaneous capillary-venous malformation associated with cerebral capillary malformation. Hum Mol Genet 2000; 22: 1351-1355.

18 Zhang J, Clatterbuck RE, Rigamonti D, Dietz HC: Mutations in KRIT1 in familial cerebral cavernous malformations. Neurosurgery 2000; 46: $1272-1277$.

19 Zhang J, Clatterbuck RE, Rigamonti D, Chang DD, Dietz HC: Interaction between Krit1 and Icap1 infers perturbation of integrin $\beta 1$-mediated angiogenesis in the pathogenesis of cerebral cavernous malformation. Hum Mol Genet 2001; 10: 2953-2960.

20 Zawistowski JS, Serebriiski IG, Lee MF, Golemis EA, Marchuk DA Krit1 association with the integrin-binding protein icap1: a new direction in the elucidation of cerebral cavernous malformations (CCM1) pathogenesis. Hum Mol Genet 2002; 11: 389-396.

21 Orita M, Iwahana H, Kanazawa H, Hayashi K, Sekiya T: Detection of polymorphisms of human DNA by gel electrophoresis as single-strand conformation polymorphisms. Proc Natl Acad Sci USA 1989; 86: 2766-2770.

22 Antonarakis SE, the Nomenclature Working Group: Recommendations for a nomenclature system for human gene mutations. Hum Mutat 1998; 11: 1-3.

23 Liu HX, Cartegni L, Zhang MQ, Krainer AR: A mechanism for exon skipping caused by nonsense or missense mutations in BRCA1 and other genes. Nat Genet 2001; 27: 55-58.

24 Schwarze U, Schievink WI, Petty E et al: Haploinsufficiency for one COL $3 A 1$ allele of type III procollagen results in a phenotype similar to the vascular form of Ehler-Danlos syndrome, EhlerDanlos type IV. Am J Hum Genet 2001; 69: 989-1001.

25 Wenstrup JR, Florer JB, Willing MC et al: COL5A1 haploinsufficiency is a common molecular mechanism underlying the classical form of EDS. Am J Hum Genet 2000; 66: 1766-1776.

26 Frischmeyer PA, Dietz HC: Nonsense-mediated mRNA decay in health and disease. Hum Mol Genet 1999; 8: 1893-1900.

27 Byers PH: Killing the messenger: new insights into nonsensemediated mRNA decay. J Clin Invest 2002; 109: 3-6. 